\title{
Pengaruh Pemberian Infusa Bawang Dayak (Eleutherine palmifolia) terhadap Gambaran Mikroskopik Ginjal Mencit yang Diinduksi $\mathrm{CCl}_{4}$
}

\author{
Erma Mexcorry Sumbayak ${ }^{1}$, Nia Vebriyani ${ }^{2}$ \\ ${ }^{1}$ Departemen Histopatologi Fakultas Kedokteran dan Ilmu Kesehatan Universitas Kristen \\ Krida Wacana \\ ${ }^{2}$ Fakultas Kedokteran dan Ilmu Kesehatan Universitas Kristen Krida Wacana \\ Alamat Korespondensi: summexco@yahoo.com
}

\begin{abstract}
Abstrak
Bawang dayak mengandung senyawa metabolit sekunder golongan naftokuinon yang diketahui memiliki bioaktivitas sebagai antikanker dan antioksidan, dan biasanya terdapat di dalam sel vakuola dalam bentuk glikosida. Tujuan dari penelitian ini adalah untuk mengetahui pengaruh pemberian infusa bawang dayak terhadap perubahan gambaran histologi ginjal mencit yang diinduksi karbon tetraklorida $\left(\mathrm{CCl}_{4}\right) . \mathrm{CCl}_{4}$ adalah senyawa kimia yang tidak berwarna, mudah menguap, berbau tajam dan bersifat toksik terhadap ginjal yang dapat mengakibatkan kerusakan pada epitel tubulus ginjal. Penelitian ini merupakan penelitian eksperimental laboratorik menggunakan sampel 25 ekor mencit jantan yang dibagi menjadi lima kelompok. Kelompok pertama sebagai kontrol $(\mathrm{K})$ diberi minyak kelapa $0,1 \mathrm{~mL}$ secara oral selama sepuluh hari pertama. Kelompok perlakuan I (P1), perlakuan II (P2), perlakuan III (P3), dan perlakuan IV (P4) diberi $\mathrm{CCl}_{4} 0,007 \mathrm{~mL} / 20 \mathrm{~g} \mathrm{BB} /$ hari yang dilarutkan dalam $0,1 \mathrm{~mL}$ minyak kelapa secara oral selama sepuluh hari pertama. Kelompok P2, P3, dan P4 diberi perlakuan infusa bawang dayak masing-masing dosis $0,06 \mathrm{~mL} / \mathrm{hari} ; 0,12 \mathrm{~mL} /$ hari; dan $0,24 \mathrm{~mL} /$ hari secara oral selama sepuluh hari kedua. Hasil penelitian menunjukkan bahwa infusa bawang dayak dapat menurunkan tingkat nekrosis epitel tubulus ginjal yang berbeda secara signifikan $(p<0,05)$ antara kelompok P1 terhadap P3 dan P4, dan tidak pada P2. Dosis yang paling baik mengurangi tingkat nekrosis epitel tubulus ginjal mencit yaitu pada P4 dengan dosis bawang dayak sebesar 0,24 mL/hari.
\end{abstract}

Kata kunci : bawang dayak, ginjal, karbon tetraklorida

\section{The Effect of Dayak Onion Infusion (Eleutherine palmifolia) on the Microscopic Appearance of the Kidneys in Mice Induced by $\mathrm{CCl}_{4}$}

\begin{abstract}
Dayak onions contain the secondary metabolites naftokuinon group, which are known to have bioactivity as anticancer and antioxidant usually found in the cell vacuole in the form of glycosides. The purpose of this study is to determine the effect of infuse dayak onion to changes in renal histology of mice induced by carbon tetrachloride $\left(\mathrm{CCl}_{4}\right) . \mathrm{CCl}_{4}$ is a chemical compound that is a colorless, volatile, pungent and toxic to the kidneys which can lead to damage to the renal tubular epithelium. This laboratory experimental study used a sample of 25 male mice divided into five groups. The first group, as a control, received $0,1 \mathrm{ml}$ coconut oil orally for the first 10 days. Treatment groups I (P1), II (P2), III (P3) and IV (P4) were given 0,007 mL/20gramBB/day of CCl4 dissolved in 0, $1 \mathrm{~mL}$ of coconut oil orally for the first 10 days. Groups P2, P3 and P4 were given 0,06 $\mathrm{mL} /$ day; 0,12 $\mathrm{mL} /$ day; and 0,24 $m L /$ day of dayak onion infusions orally respectively for ten days. The results showed that dayak onion infusion reduced the level of renal tubular epithelial necrosis, at a significant difference $(p<0,05)$ between groups $P 1$ to $P 3$ and $P 4$, and not on $P 2$. The best dose to reduce rate of renal tubular epithelial necrosis mice was in the P4 group, with dayak onion infusions of 0,24 $\mathrm{mL} /$ day.
\end{abstract}

Keywords: dayak onions, kidney, carbon tetrachloride, 


\section{Pendahuluan}

Masyarakat Indonesia telah lama mengenal dan menggunakan tanaman berkhasiat obat sebagai salah satu upaya dalam menanggulangi masalah kesehatan. Pengetahuan tentang tanaman berkhasiat obat berdasar pada pengalaman dan ketrampilan yang telah diwariskan secara turun-temurun. ${ }^{1}$ Banyak obat herbal yang telah diterima secara luas di hampir seluruh negara di dunia. Menurut World Health Organization (WHO), negaranegara di Afrika, Asia, dan Amerika Latin menggunakan obat herbal sebagai pelengkap pengobatan primer yang mereka terima. Keunggulan pengobatan herbal terletak pada bahan dasarnya yang bersifat alami sehingga efek sampingnya dapat ditekan seminimal mungkin. ${ }^{2}$

Bawang dayak (Eleutherine palmifolia (L.) Merr.) merupakan tumbuhan di hutan Kalimantan yang biasa digunakan oleh masyarakat pedalaman Kalimantan Tengah menjadi ramuan atau obat tradisional. ${ }^{3}$ Pada umumnya bagian tanaman yang digunakan adalah umbi dan daun (Gambar 1). ${ }^{4}$

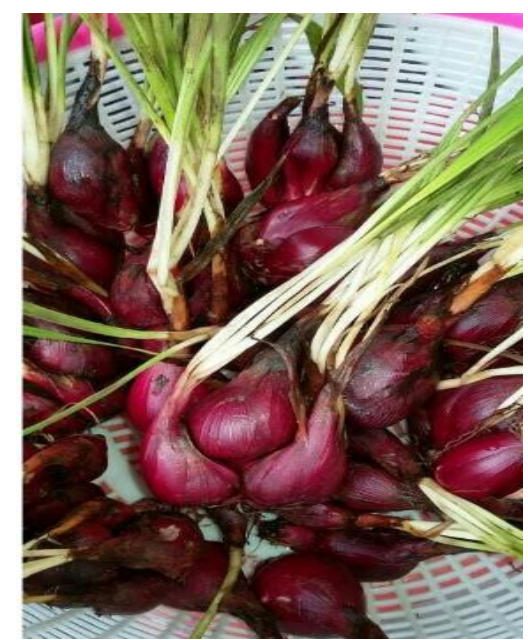

Gambar 1. Bawang Dayak

Tanaman bawang dayak memiliki banyak manfaat yaitu sebagai antiradang, menghentikan perdarahan, dan antitumor. ${ }^{3}$ Umbi tumbuhan genus Eleutherine ini dari beberapa penelitian diketahui mengandung senyawa metabolit sekunder golongan naftokuinon (elecanacin, eleutherin, elutherol, eleutherinon). ${ }^{3}$ Naftokuinon dikenal sebagai antimikroba, antifungal, antiviral, dan antiparasit. Beberapa senyawa turunan naftokuinon diketahui memiliki bioaktivitas sebagai antikanker dan antioksidan yang biasanya terdapat di dalam sel vakuola dalam bentuk glikosida. ${ }^{4}$

Ginjal normal memunyai tiga fungsi pokok yaitu: filtrasi glomerular oleh glomerulus, reabsorbsi oleh tubulus, dan sekresi tubular oleh tubulus. ${ }^{5}$ Ginjal menghasilkan urin yang merupakan jalur utama ekskresi toksikan. Ginjal memunyai volume aliran darah yang tinggi, mengonsentrasi toksikan pada filtrat, dan membawa toksikan melalui sel tubulus, serta mengaktifkan toksikan tertentu. Akibatnya ginjal merupakan organ sasaran utama dari efek toksik. ${ }^{6}$

Banyak sekali permasalahan yang dapat terjadi pada struktur dan fungsi sel pada ginjal akibat radikal bebas. Radikal bebas merupakan salah satu produk reaksi kimia dalam tubuh yang bersifat sangat reaktif dan mengandung elektron yang tidak berpasangan pada orbital luarnya sehingga bersifat tidak stabil. Oleh karena bersifat reaktif, maka radikal bebas menimbulkan perubahan kimiawi dan merusak komponen sel hidup seperti protein, lipid, karbohidrat dan asam nukleat. ${ }^{5}$ Peningkatan produksi radikal bebas dapat menyebabkan kelainan pada berbagai organ target misalnya pada ginjal. ${ }^{5}$ Tetapi, tubuh juga memunyai mekanisme yang dapat menetralisasi bahaya radikal bebas dengan sistem antioksidan. ${ }^{5}$

Penelitian ini menguji upaya mengatasi kerusakan pada ginjal menggunakan bawang dayak. Penelitian dilakukan dengan objek ginjal mencit yang telah diinduksi dengan karbon tetraklorida, yang merupakan senyawa kimia organik volatil (senyawa yang mudah menguap terutama jika terjadi kenaikan suhu), yang dapat menyebabkan kerusakan jaringan, khususnya pada hati dan ginjal. ${ }^{7}$ Salah satu gangguan pada ginjal akibat produksi radikal bebas yang berlebih salah satunya adalah Acute Tubular Necrocis (ATN) yang menyerang tubulus ginjal..$^{5}$ ATN (Acute Tubular Necrosis) adalah suatu entilas klinikopatologik, dengan morfologis kerusakan sel epitel dan secara klinis oleh penurunan atau hilangnya fungsi ginjal secara akut. Kelainan ini merupakan penyebab tersering gagal ginjal akut. ${ }^{8}$

Pada nekrosis tubuler akut nefrotoksik terjadi nekrosis segmen-segmen pendek tubulus, terutama pada tubulus proksimal, dengan membrana basalis tubulus umumnya masih baik dan secara klinik terjadi supresi akut fungsi ginjal. ${ }^{9}$ Secara histologis ditandai 
dengan sel-sel epitel tubulus yang semakin menipis dan datar, brush border menghilang, lumen tubulus melebar dan terisi oleh jaringan nekrotik. ${ }^{9}$ Nekrosis pada tubulus medularis mengandung silinder granular dari detritus sel tubulus proksimal nekrotik yang terlepas. ${ }^{10} \mathrm{Hal}$ ini terjadi karena sel epitel tubulus ginjal peka terhadap anoksia dan mudah rusak karena keracunan saat kontak dengan zat-zat yang diekskresi oleh ginjal. ${ }^{10}$

Karbon tetraklorida $\left(\mathrm{CCl}_{4}\right)$ adalah senyawa kimia yang tidak berwarna, mudah menguap, berbau tajam, dan bersifat toksik terhadap ginjal (nefrotoksik). ${ }^{11}$ Metabolisme $\mathrm{CCl}_{4}$ menghasilkan radikal bebas Carbon triklorida $\left(\mathrm{CCl}_{3}\right)$ yang dapat mengakibatkan kerusakan pada epitel tubulus ginjal. ${ }^{11} \mathrm{CCl}_{4}$ digunakan sebagai pembersih, penghilang noda pakaian, perabot rumah tangga, karpet, dan lain-lain. $\mathrm{CCl}_{4}$ masuk ke dalam tubuh melalui paru-paru, gastrointestinal, dan kulit. ${ }^{11} \mathrm{CCl}_{4}$ dapat merusak hati, ginjal, sistem saraf, dan lain-lain. Toksisitas karbon tetraklorida bergantung pada spesies, strain hewan coba, rute pemberian, dan dosisnya. ${ }^{12}$

\section{Metode Penelitian}

\section{Bahan dan Alat}

Bahan yang digunakan dalam penelitian ini adalah larutan $\mathrm{CCl}_{4}$, minyak kelapa, infusa bawang dayak, akuades, dan makanan hewan percobaan (pelet dan air PAM). Alat yang digunakan adalah mencit 25 ekor, kandang hewan percobaan untuk lima kelompok hewan percobaan, timbangan digital, gelas ukur dan pengaduk, kertas saring, sonde lambung berbentuk jarum (needle gayage), disposable syringe berukuran $1 \mathrm{~mL}$, alat pembedahan hewan percobaan (pinset, jarum pentul, pisau bedah, kapas, gunting anatomis, jarum, meja lilin, beaker glass $150 \mathrm{~mL}$, dan botol kaca bening $18 \mathrm{~mL}$ ), alat untuk pembuatan sediaan histologis ginjal, serta mikroskop cahaya.

\section{Sampel}

Penentuan jumlah sampel penelitian dihitung menurut rumus Federer. Berdasarkan perhitungan tersebut didapatkan jumlah subjek yang akan dipakai dalam penelitian adalah lima ekor mencit pada setiap kelompoknya, sehingga jumlah total mencit yang digunakan adalah 25 ekor.

\section{Penentuan Dosis $\mathrm{CCl}_{4}$}

Dosis $\mathrm{CCl}_{4}$ yang digunakan adalah $0,007 \mathrm{~mL} / 20 \mathrm{~g}$ berat badan/hari yang dilarutkan dalam 0,1 $\mathrm{mL}$ minyak kelapa. Pemberian $\mathrm{CCl}_{4}$ ini dilakukan menggunakan sonde lambung dan dilakukan selama sepuluh hari. Minyak kelapa digunakan sebagai pelarut, karena $\mathrm{CCl}_{4}$ merupakan senyawa kimia yang larut di dalam minyak. Uji dilakukan berdasarkan pada penelitian yang menunjukkan bahwa dosis tersebut dapat berdampak nefrotoksik.$^{13}$

\section{Pembuatan Infusa Simplisia Bawang Dayak}

Umbi bawang dayak (Eleutherine palmifolia (L.) Merr.) yang masih segar dibersihkan dari kotoran dan tanah kemudian dicuci dengan air mengalir dan diriis tipis dengan ketebalan sekitar satu milimeter. Infusa bawang dayak dengan dosis $10 \%$ dibuat dengan menambahkan akuades $100 \mathrm{~mL}$ pada sepuluh gram simplisia bawang dayak. Larutan dipanaskan di dalam oven dengan suhu $90^{\circ} \mathrm{C}$ selama 15 menit. Setelah itu penyaringan dilakukan dengan menggunakan kertas saring, untuk membuang ampas bawang dayak. Infusa simplisia bawang dayak $10 \%$ dapat disimpan pada suhu $4^{\circ} \mathrm{C}$. Hasil infusa yang telah didapat dilarutkan/diencerkan dengan memasukkan 1 $\mathrm{mL}$ infusa bawang dayak ke dalam $10 \mathrm{~mL}$ akuades. Infusa bawang dayak dibuat dalam tiga dosis: dosis I sebesar $0,06 \mathrm{~mL} / \mathrm{hari}$ (dosis rendah), dosis II sebesar $0,12 \mathrm{~mL} / \mathrm{hari}$ (dosis sedang), dan dosis III sebesar $0,24 \mathrm{~mL} / \mathrm{hari}$ untuk dosis tinggi. Ketiga dosis ini didapatkan berdasarkan pengalaman masyarakat yang memakai lima siung bawang dayak per hari pada manusia, yang kemudian dikonversikan ke dosis mencit dan berdasarkan kapasitas lambung mencit.

\section{Pelaksanaan Percobaan}

1) Kelompok kontrol (K) terdiri atas lima ekor mencit yang diberi makan dan air minum kemasan ad libitum selama 20 hari berturut-turut, dan pemberian minyak kelapa $0,1 \mathrm{~mL}$ secara oral selama 10 hari pertama.

2) Kelompok perlakuan I (P1) terdiri atas lima ekor mencit yang diberi makan dan 
air minum kemasan ad libitum selama 20 hari berturut-turut, dan diberi $\mathrm{CCl}_{4} 0,007$ $\mathrm{mL} / 20 \mathrm{~g}$ berat badan yang telah dilarutkan dalam $0,1 \mathrm{~mL}$ minyak kelapa secara oral selama sepuluh hari pertama.

3) Kelompok perlakuan II (P2) terdiri atas lima ekor mencit yang diberi makan dan air minum kemasan ad libitum selama 20 hari berturut-turut, dan diberi $\mathrm{CCl}_{4} 0,007$ $\mathrm{mL} / 20 \mathrm{~g}$ berat badan/hari yang telah dilarutkan dalam $0,1 \mathrm{~mL}$ minyak kelapa secara oral selama sepuluh hari pertama, serta diberi infusa simplisia bawang dayak $10 \%$ dengan volume $0,06 \mathrm{~mL} /$ hari secara oral selama sepuluh hari kedua.

4) Kelompok perlakuan III (P3) terdiri atas lima ekor mencit yang diberi makan dan air minum kemasan ad libitum selama 20 hari berturut-turut, dan diberi $\mathrm{CCl}_{4} 0,007$ $\mathrm{mL} / 20 \mathrm{~g}$ berat badan/hari yang telah dilarutkan dalam $0,1 \mathrm{~mL}$ minyak kelapa secara oral selama sepuluh hari pertama, serta diberi infusa simplisia bawang dayak $10 \%$ dengan volume $0,12 \mathrm{~mL} /$ hari secara oral selama sepuluh hari kedua.

5) Kelompok perlakuan IV (P4) terdiri atas lima ekor mencit yang diberi makan dan air minum kemasan ad libitum selama 20 hari berturut-turut, dan diberi $\mathrm{CCl}_{4} 0,007$ $\mathrm{mL} / 20 \mathrm{~g}$ berat badan/hari yang telah dilarutkan dalam $0,1 \mathrm{~mL}$ minyak kelapa secara oral selama sepuluh hari pertama, serta diberi infusa simplisia bawang dayak $10 \%$ dengan volume $0,24 \mathrm{~mL} /$ hari secara oral selama sepuluh hari kedua.

\section{Pengukuran Hasil}

Dalam penelitian ini seluruh data hasil penelitian dianalisis dengan menggunakan SPSS Versi 16.0, dengan langkah uji pertama dengan uji Saphiro-Wilk untuk mengetahui distribusi data (distribusi normal; $\mathrm{p}>0,05)$, dan analisis varian (Uji Leven's) untuk mengetahui homogenitas varian antarkelompok hewan uji (varians homogen; $\mathrm{p}>0,05$ ). Jika data terdistribusi normal dan homogen, maka analisis dilanjutkan dengan analisis variansi pola searah (One Way ANOVA) dengan taraf kepercayaan $95 \%$ untuk mengetahui perbedaan kelompok. Selanjutnya dilakukan uji Post Hoc Turkey untuk melihat apakah perbedaan antarkelompok bermakna secara statistik $(\mathrm{p}<0,05)$.

\section{Kaji Etik}

Penelitian ini dinyatakan telah lolos kaji etik dengan nomor 053/SLKEIV/UKKW/FK/KE/1/2017 dari Komite Etik Fakultas Kedokteran dan Ilmu Kesehatan Universitas Kristen Krida Wacana.

\section{Hasil dan Pembahasan}

Hasil penelitian pada gambaran histologi ginjal mencit yang diinduksi karbon tetraklorida $\left(\mathrm{CCl}_{4}\right)$ dengan perlakuan pemberian infusa bawang dayak dengan tingkat dosis yang berbeda, dapat diuraikan dalam gambar-gambar sebagai berikut.

Gambar 2 merupakan hasil pengamatan tingkat nekrosis epitel tubulus ginjal mencit dengan perbesaran 400x. Nekrosis pada epitel tubulus ditandai dengan adanya penipisan pada sitoplasma yang ditunjuk dengan tanda garis. Pembacaan preparat dilakukan dengan cara mengamati preparat ginjal kiri dan kanan. Masing-masing ginjal dihitung jumlah epitel tubulus yang mangalami penipisan dengan gambaran tubulus kontrol (K) sebagai pembanding. Penilaian dan pengamatan tingkat nekrosis tubulus ginjal dilakukan dengan menggunakan mikroskop cahaya dengan perbesaran 40x, 100x, dan 400x. Kemudian epitel yang nekrosis pada kedua ginjal dijumlahkan, sehingga didapatkan jumlah dari masing-masing mencit, lalu dirata-ratakan. Hasil perhitungan dibuat dalam bentuk grafik seperti terlihat pada gambar 3 . 


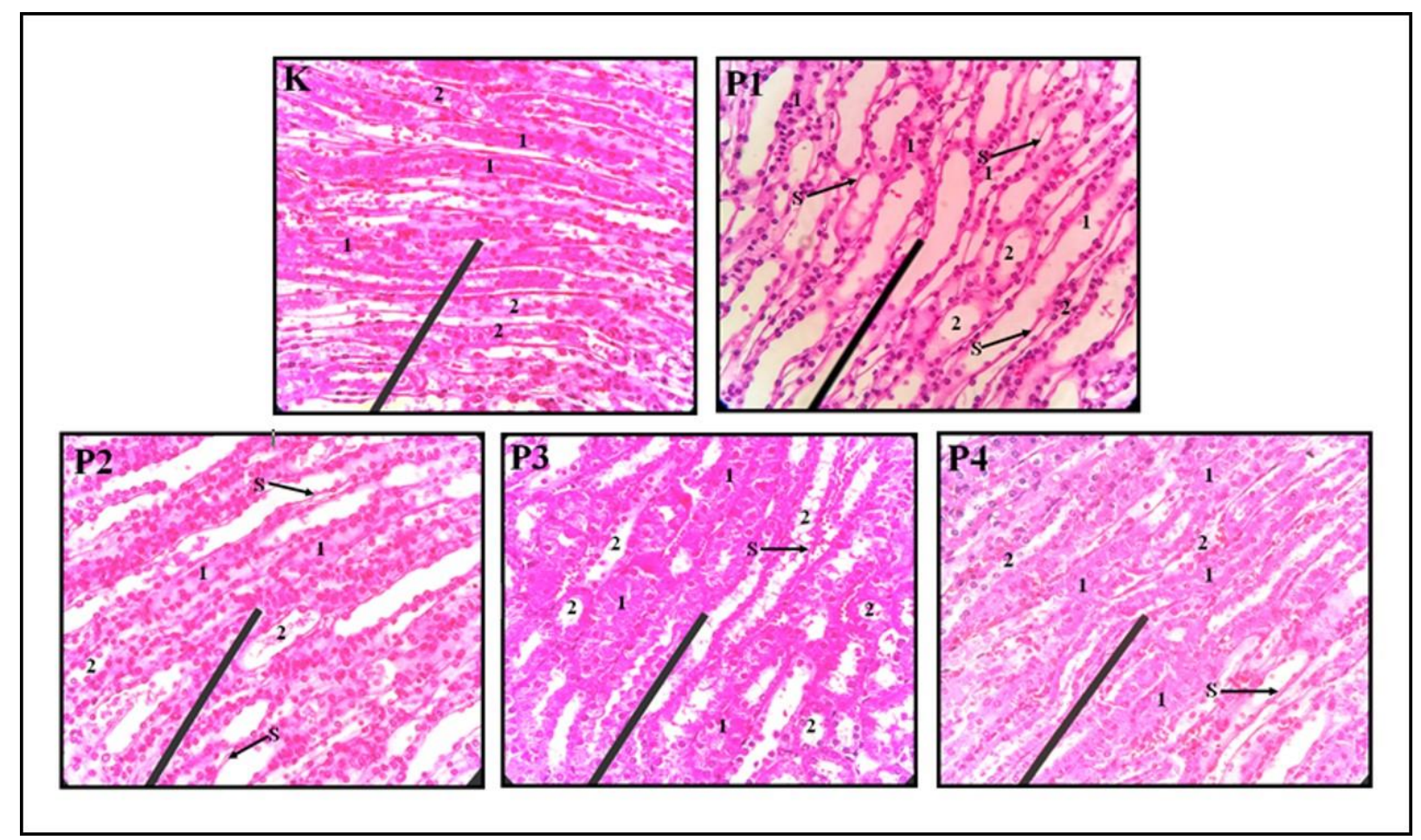

Gambar 2. Mikroanatomi Medula Ginjal Mencit yang Mengalami Nekrosis pada Epitel Tubulus yang Diinduksi CCl4 dan Diberikan Infusa Bawang Dayak 10\% sebagai Antioksidan (pewarnaan HE, pembesaran 400x)

Keterangan: (1) Tubulus rektus proksimal; (2) Tubulus rektus distal; (S) Penipisan sitoplasma

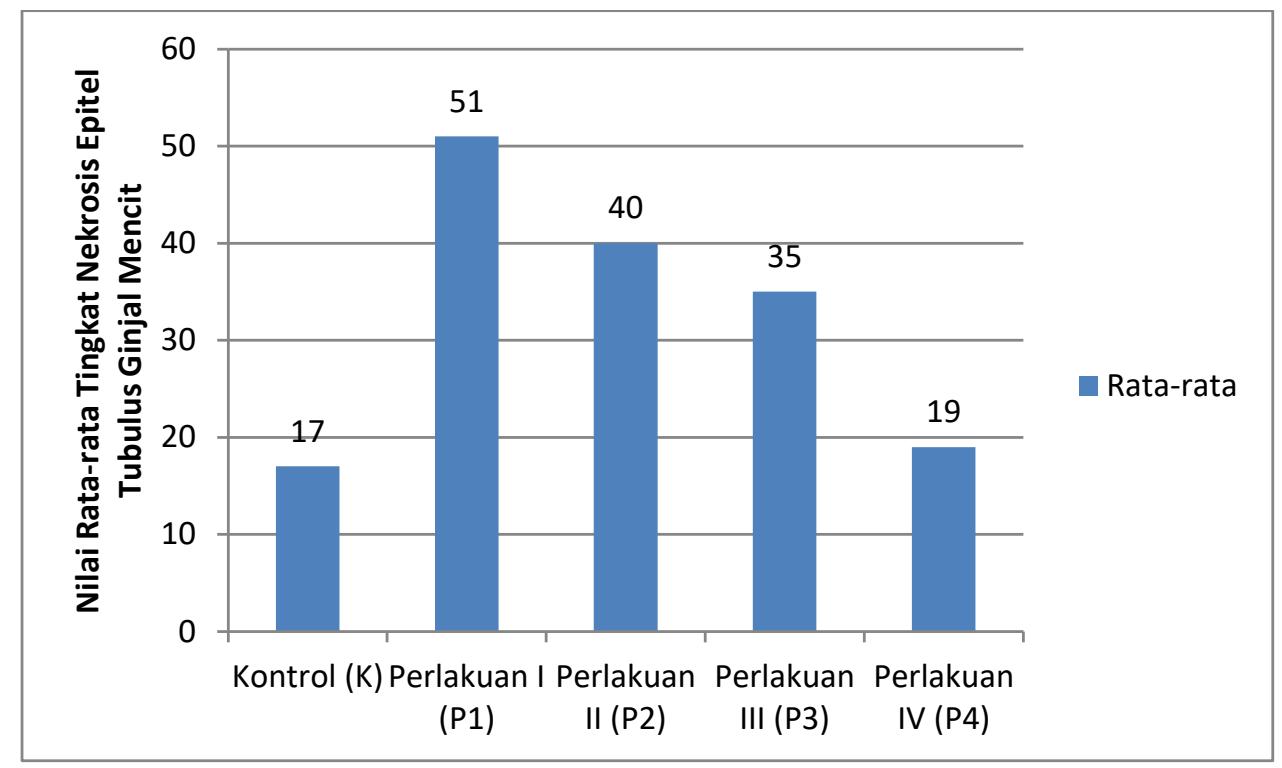

Gambar 3. Grafik Hasil Pengamatan Nilai Rata-Rata Tingkat Nekrosis Epitel Tubulus Ginjal Mencit

$$
\begin{aligned}
& \text { Keterangan : } \mathrm{K}=\text { Kontrol } \\
& \mathrm{P} 1=\mathrm{CCl} 40,007 \mathrm{~mL} / 20 \mathrm{~g} \text { berat badan } / \text { hari } \\
& \mathrm{P} 2=\mathrm{CCl} 40,007 \mathrm{~mL} / 20 \mathrm{~g} \text { berat badan/hari }+ \text { infusa bawang dayak } 10 \% 0,06 \mathrm{~mL} / \mathrm{hari} \\
& \mathrm{P} 3=\mathrm{CCl} 40,007 \mathrm{~mL} / 20 \mathrm{~g} \text { berat badan/hari }+ \text { infusa bawang dayak } 10 \% \text { 0,12 mL/hari } \\
& \mathrm{P} 4=\mathrm{CCl} 40,007 \mathrm{~mL} / 20 \mathrm{~g} \mathrm{BB} / \text { hari }+ \text { infusa bawang dayak } 10 \% \text { 0,24 mL/hari }
\end{aligned}
$$


Berdasarkan uji Shapiro-Wilk yang diikuti uji Leven's, data jumlah tingkat nekrosis epitel tubulus ginjal mencit dianalisis terdistribusi normal dan homogen. Setelah itu, dilakukan uji One Way ANOVA dan uji Pos Hoc Turkey untuk melihat perbedaan bermakna antarkelompok.

Tabel 1. Hasil uji One Way ANOVA Pengaruh Pemberian Infusa Bawang Dayak terhadap Tingkat Nekrosis Epitel Tubulus Ginjal Mencit yang Diinduksi $\mathrm{CCl}_{4}$

\begin{tabular}{cccccc}
\hline & Sum of Squares & $\boldsymbol{d f}$ & Mean Square & $\boldsymbol{F}$ & Sig. \\
\hline Perlakuan & 4136,000 & 4 & 1034,000 & $10,771^{*}$ &, 000 \\
Galat & 1920,000 & 20 & 96,000 & & \\
Total & 6056,000 & 24 & & & \\
\hline
\end{tabular}

Keterangan : *p $<0,05$ (berbeda bermakna)

Dari tabel di atas, terlihat bahwa $\mathrm{p}<$ 0,05 , yang menunjukkan bahwa terdapat pengaruh pemberian bawang dayak terhadap tingkat nekrosis epitel tubulus ginjal mencit yang diinduksi $\mathrm{CCl}_{4}$. Untuk mengetahui ada tidaknya perbedaan dari tiap perlakuan serta dosis mana yang paling efektif, maka dilakukan uji Post Hoc Turkey. Berdasarkan hasil uji Post Hoc Turkey dan didapatkan bahwa terdapat perbedaan yang nyata terhadap penurunan tingkat nekrosis epitel tubulus ginjal mencit setelah diberi infusa bawang dayak dengan dosis yang berbeda. Perlakuan pemberian infusa bawang dayak pada dosis II dan dosis III memberikan hasil yang signifikan/berbeda nyata terhadap kontrol positif, tetapi tidak berbeda nyata dengan dosis I. Jadi, infusa bawang dayak dapat menurunkan tingkat nekrosis atau kematian sel epitel tubulus ginjal mencit yang diinduksi $\mathrm{CCl}_{4}$ dan dosis yang paling baik adalah dosis III pada perlakuan IV (P4) dengan pemberian infusa umbi dayak 0,24 $\mathrm{mL} /$ hari, meskipun sel epitel tubulus ginjal masih belum menunjukkan kondisi normal. Hal ini disebabkan karena efek bawang dayak yang melindungi ginjal terhadap kerusakan lebih lanjut.

Beberapa penelitian tentang bawang dayak telah dilakukan, antara lain dengan bulbus tanaman genus Eleutherine. Bulbus tanaman Eleutherine bulbosa dan Eleutherine americana diketahui mengandung senyawa metabolit sekunder golongan naftokuinon (elecanacin, eleutherin, eleutherol, eleutherinon). ${ }^{14}$ Banyak senyawa turunan naftokuinon yang diketahui memiliki bioaktivitas sebagai antikanker maupun antioksidan, selain itu bersifat sangat toksik, umumnya digunakan sebagai antimikroba, antifungal, antiviral, dan antiparasit. ${ }^{14}$ Ginjal merupakan organ tubuh yang vital karena berfungsi sebagai organ ekskresi zat-zat sisa metabolisme. ${ }^{15}$ Pada proses ekskresi tersebut ginjal dapat mengalami kerusakan karena zat yang diekskresikan berupa zat yang toksik bagi tubuh. ${ }^{15}$

Karbon tetraklorida merupakan salah satu senyawa model yang bersifat hepatotoksin dan nefrotoksin. ${ }^{16}$ Induksi karbon tetraklorida dapat merangsang terjadinya sirosis pada tikus dan menghasilkan oksidatif stres pada ginjal melalui peroksidasi lipid dan protein. ${ }^{16}$ Peroksidasi lipid selanjutnya mengubah DNA mitokondria dan mengganggu kestabilan membran sel, propagasi siklus oksidatif stres secara besar-besaran yang diikuti dengan peradangan. ${ }^{17}$ Pemberian $\mathrm{CCl}_{4}$ dapat meningkatkan kadar kreatinin urin, protein, dan urobilinogen. Secara histopatologis, $\mathrm{CCl}_{4}$ dapat mengakibatkan terjadinya steatosis, nekrosis sentrolobular, dan sirosis di hati serta akut tubuler nekrosis di ginjal. ${ }^{16}$ Radikal bebas trichloromethyl $\left(\mathrm{CCl}_{3^{-}}\right)$yang dihasilkannya dapat mengakibatkan kerusakan pada tubulus proksimal ginjal. ${ }^{16}$ Kerusakan ini tidak disertai dengan kerusakan membran basalis, sehingga memungkinkan untuk terjadinya regenerasi sel epitelnya. ${ }^{16}$ Oleh karena itu, Acute Tubular Necrocis (ATN) yang disebabkan karena $\mathrm{CCl}_{4}$ ini bersifat reversibel. ${ }^{11}$

Karbon tetraklorida yang digunakan sebagai penginduksi bersifat nefrotoksik terutama pada bagian tubulus proksimal. ${ }^{11}$ Oleh karena itu, pengamatan dilakukan pada bagian tubulus dengan cara membandingkan gambaran pada kelompok dosis, normal, dan induksi. 
Pada penelitian ini, dilakukan pemberian berulang $\mathrm{CCl}_{4}$ 0,007 mL/20 g berat badan/hari dengan sonde lambung selama sepuluh hari untuk menginduksi nekrosis ginjal. Nekrosis yang terjadi disebabkan karena $\mathrm{CCl}_{4}$ di dalam tubuh dimetabolisme oleh enzim sitokrom $\mathrm{P}_{450}$ dan menghasilkan radikal bebas $\mathrm{CCl}_{3}^{-}$yang menyebabkan proses autooksidasi dan menghasilkan radikal lipid yang tidak stabil. ${ }^{11}$ Hal ini selanjutnya mengakibatkan peroksidasi lipid, yang dapat menyebabkan kerusakan membran sel, kerusakan mitokondria, denaturasi protein sel, dan berakhir pada kematian sel. ${ }^{10}$ Nekrosis pada tubulus medularis mengandung silinder granular dari detritus sel tubulus proksimal nekrotik yang terlepas. $^{18}$

Pada nekrosis tubuler akut, terjadi nekrosis segmen-segmen pendek tubulus, terutama pada tubulus proksimal. Membrana basalis tubulus umumnya masih baik dan secara klinik terjadi supresi akut fungsi ginjal. Secara histologis, hal ini ditandai dengan sel-sel epitel tubulus yang semakin menipis dan datar, brush border yang menghilang, serta lumen tubulus yang melebar dan terisi oleh jaringan nekrotik. ${ }^{9}$
Hal ini terjadi karena sel epitel tubulus ginjal peka terhadap anoksia dan mudah rusak karena keracunan saat kontak dengan zat-zat yang diekskresi oleh ginjal. ${ }^{9}$

Kerusakan berupa infiltrasi sel radang juga ditemukan pada sebagian besar korteks ginjal (Gambar 3), yang ditandai oleh gambaran limfosit berwarna ungu kebiruan dan bergerombol di beberapa bagian korteks ginjal. Peradangan merupakan respons terhadap kerusakan sel oleh pembuluh darah dan jaringan ikat. Adanya reaksi peradangan ini berguna untuk memertahankan keseimbangan dan gangguan fungsi jaringan dari bahaya. ${ }^{14}$ Senyawa flavonoid pada ekstrak bawang dayak dapat menstimulasi sistem imun, antiviral, antikanker, mengurangi risiko penyakit kardiovaskuler, antiinflamasi dan penangkal radikal bebas. ${ }^{19}$

Senyawa-senyawa yang terdapat pada bawang dayak, yaitu alkaloid, glikosida, fenolik, steroid, flavonoid, tannin dapat berperan sebagai antioksidan yang mampu menghambat pembentukan dan aktivitas radikal bebas sehingga dapat mencegah kerusakan sel yang lebih berat. $^{20}$

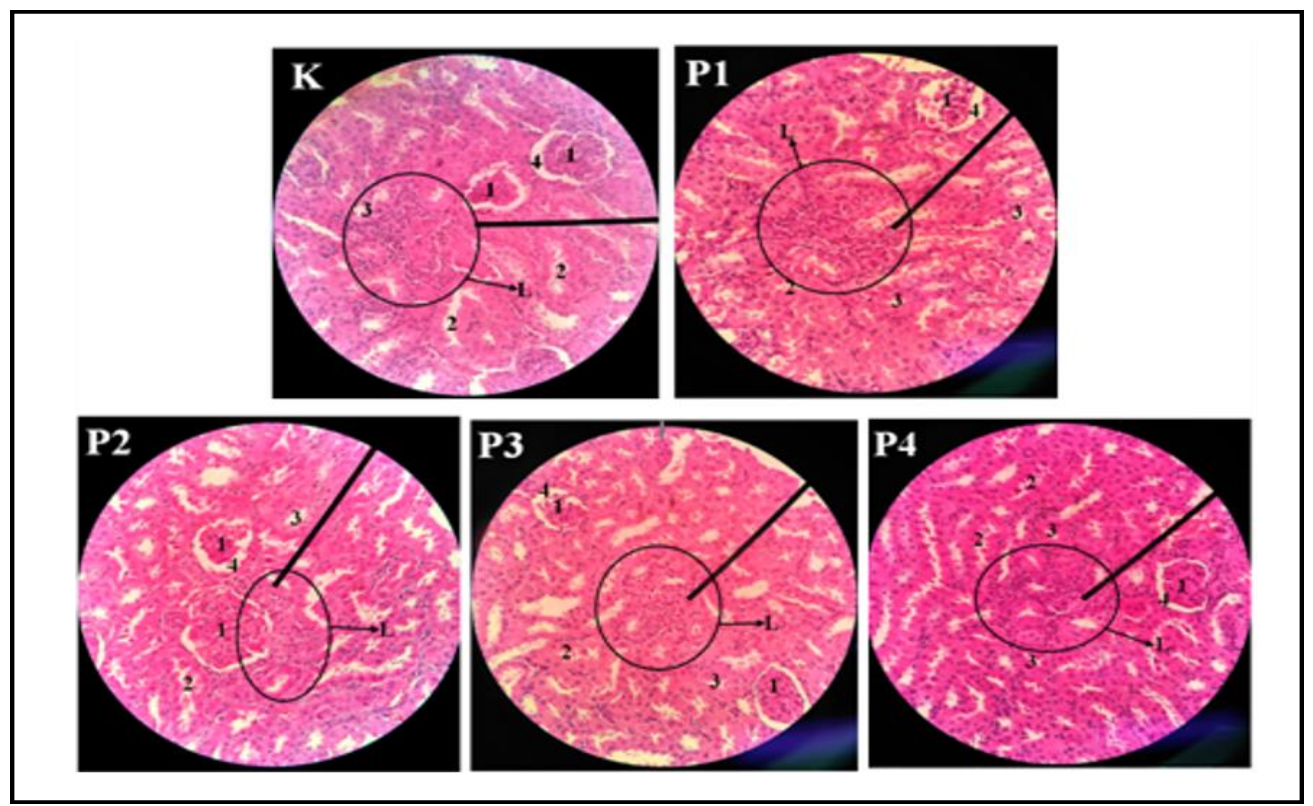

Gambar 4. Mikroanatomi Ginjal Mencit yang terdapat Lokasi Infiltrasi Limfosit yang Diinduksi $\mathrm{CCl}_{4}$ dan Diberikan Infusa Bawang Dayak 10\% sebagai Antioksidan (pewarnaan HE, pembesaran 40x)

Keterangan : (1) Glomerulus; (2) T.K. Proksimal; (3) T.K. Distal; (4) Ruang Bowman; (L) Infistrasi Limfosit

Gambar 4 merupakan hasil pengamatan terhadap lokasi infiltrasi limfosit pada histologi ginjal mencit dengan perbesaran 400x. Tampak adanya limfosit berwarna ungu Sumbayak E, Vebriyani N. J. Kedokt Meditek. 2019; 25(1): 1-10 kebiruan yang bergerombol seperti yang ditunjuk dalam lingkaran. Pembacaan preparat dilakukan dengan cara mengamati preparat ginjal kiri dan kanan. Pada masing-masing 
ginjal, dihitung lokasi yang terdapat tumpukan limfositnya. Penilaian dan pengamatan lokasi yang terdapat tumpukan limfositnya dilakukan dengan menggunakan mikroskop cahaya dengan perbesaran 100x dan 400x. Kemudian total lokasi yang terdapat tumpukan limfosit pada kedua ginjal dijumlahkan, sehingga didapatkan jumlah dari masing-masing mencit, lalu dirata-ratakan. Hasil perhitungan dibuat dalam bentuk grafik seperti terlihat pada gambar 5 .

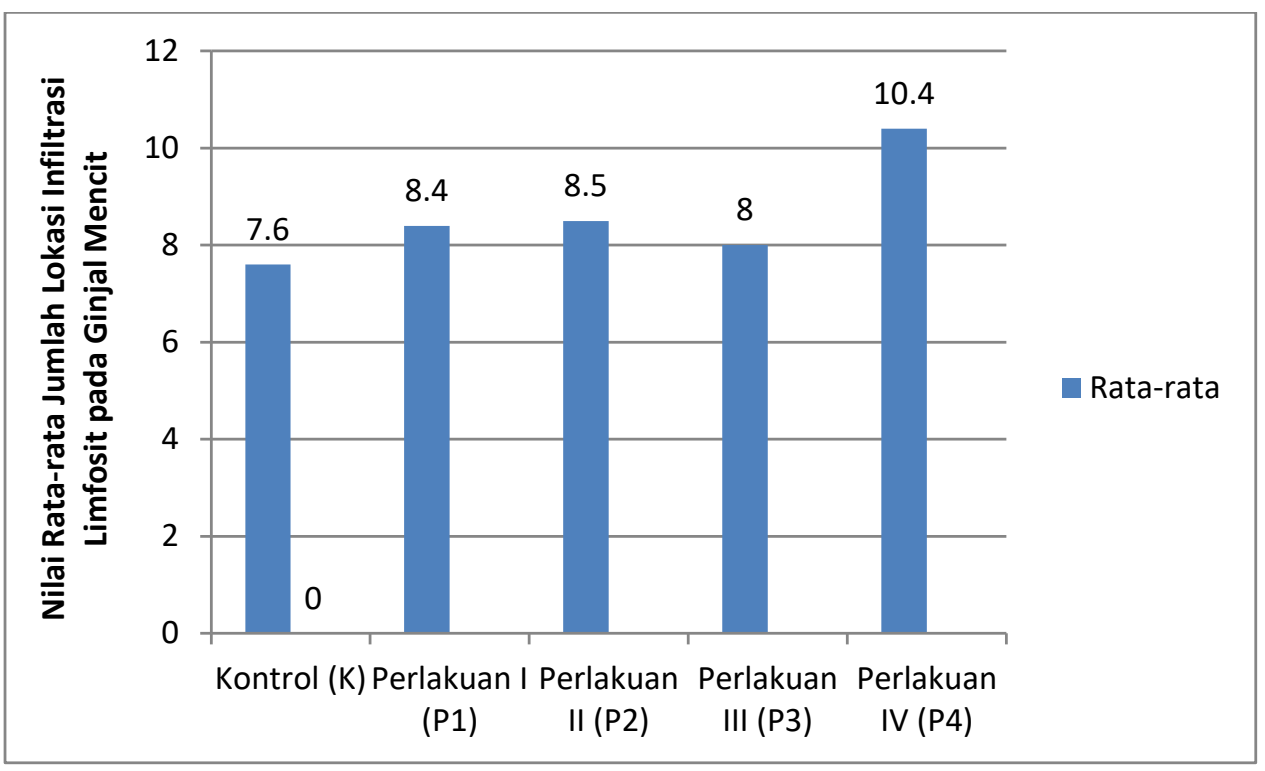

Gambar 5. Grafik Nilai Rata-Rata Jumlah Lokasi Infiltrasi Limfosit pada Ginjal Mencit

Keterangan : $\mathrm{K}=$ Kontrol

$\mathrm{P} 1=\mathrm{CCl} 40,007 \mathrm{~mL} / 20 \mathrm{~g}$ berat badan/hari

$\mathrm{P} 2=\mathrm{CCl} 40,007 \mathrm{~mL} / 20 \mathrm{~g}$ berat badan/hari + infusa bawang dayak $10 \% 0,06 \mathrm{~mL} / \mathrm{hari}$

$\mathrm{P} 3=\mathrm{CCl} 40,007 \mathrm{~mL} / 20 \mathrm{~g}$ berat badan/hari + infusa bawang dayak $10 \% 0,12 \mathrm{~mL} / \mathrm{hari}$

$\mathrm{P} 4=\mathrm{CCl} 40,007 \mathrm{~mL} / 20 \mathrm{~g}$ berat badan/hari + infusa bawang dayak $10 \%$ 0,24 mL/har

Data jumlah lokasi infiltrasi limfosit pada ginjal mencit yang telah dianalisis menggunakan uji Shapiro-Wilk dan kemudian uji Leven's, yang menunjukkan bahwa data terdistribusi normal dan homogen. Setelah itu, dilakukan uji One Way ANOVA untuk melihat perbedaan bermakna antarkelompok, dengan hasil sesuai tabel 2 .

Tabel 2. Hasil uji One Way ANOVA Pengaruh Pemberian Infusa Bawang Dayak terhadap Jumlah Lokasi Infiltrasi Limfosit

\begin{tabular}{lccccc}
\hline & Sum of Squares & df & Mean Square & F & Sig. \\
\hline Perlakuan & 92,800 & 4 & 23,200 & $0,378 *$ & 0,822 \\
Galat & 1227,200 & 20 & 61,360 & & \\
Total & 1320,000 & 24 & & & \\
\hline \multicolumn{2}{c}{ Keterangan : *p $\geq 0,05$ (tidak berbeda bermakna) } & & &
\end{tabular}


Tabel 2 menunjukkan $p>0,05$ ), dapat dikatakan bahwa tidak terdapat pengaruh nyata pada pemberian infusa bawang dayak terhadap jumlah lokasi infiltrasi limfosit pada ginjal mencit yang diinduksi $\mathrm{CCl}_{4}$. Kemungkinan jangka waktu penelitian yang singkat dan dosis yang kecil menyebabkan hasil yang didapatkan tidak signifikan. Selain itu, terdapat juga variabel luar yang tidak dapat dikendalikan, seperti kondisi psikologis yang dipengaruhi lingkungan sekitar, reaksi hipersensitivitas, dan keadaan awal ginjal mencit. ${ }^{9}$ Pemberian perlakuan yang berulang kali dan perkelahian antarmencit dapat memengaruhi kondisi psikologis mencit. Reaksi hipersensitivitas dapat terjadi karena adanya variasi kepekaan mencit terhadap zat yang digunakan. ${ }^{9}$

\section{Simpulan}

Dari penelitian yang dilakukan, dapat diambil kesimpulan bahwa infusa bawang dayak dapat menurunkan tingkat nekrosis epitel tubulus pada ginjal mencit yang diinduksi karbon tetraklorida $\left(\mathrm{CCl}_{4}\right)$. Dosis yang paling baik mengurangi tingkat nekrosis epitel tubulus adalah dosis 0,24 $\mathrm{mL} /$ hari. Namun demikian, infusa bawang dayak tidak memberikan pengaruh terhadap jumlah lokasi infiltrasi limfosit pada ginjal mencit yang diinduksi karbon tetraklorida $\left(\mathrm{CCl}_{4}\right)$. Kemungkinan ini terjadi karena kurangnya jangka waktu penelitian dan dosis yang kecil serta terdapat variabel luar yang tidak dapat dikendalikan.

\section{Daftar Pustaka}

1. Sari LORK. Pemanfaatan obat tradisional dengan pertimbangan manfaat dan keamanannya. Majalah Ilmu Kefarmasian, 2006;3(1):1-7.

2. Redaksi Agromedia. Buku pintar tanaman obat. Jakarta: PT Agromedia Pustaka. 2008.h.1.

3. Kuntorini EM. Kemampuan antioksidan bulbus bawang dayak (Eleutherine americana Merr) pada umur berbeda. Prosiding Seminar FMIPA Univeritas Lampung. 2013;297.
4. Hidayah AS, Mulkiya K, Purwanti L. Uji aktivitas antioksidan umbi bawang dayak (Eleutherine bulbosa Merr). SPeSIA Unisba. 2015;397.

5. Hanifah L. Pengaruh pemberian buah pepaya (Carica papaya. L) terhadap tingkat nekrosis epitel glomerulus dan tubulus ginjal mencit (Mus musculus) yang diinduksi $\mathrm{CCl}_{4}$ (karbon tetraklorida). Jawa Tengah: Tesis Fakultas Sains dan Teknologi Universitas Negeri Malang; 2008:94 hlm.

6. Santoso HB, Nurliani A. Efek doksisiklin selama masa organogenesis pada struktur histologi organ hati dan ginjal fetus mencit. Bioscientiae, 2006;3(1):15-27.

7. Bhara M.L.A Pengaruh pemberian kopi dosis bertingkat per oral 30 hari terhadap gambaran histologi hepar tikus. Semarang: Skripsi FK Undip; 2009:48 hlm.

8. Vitnay KR, Cotran. Dasar patologis penyakit. Ed-7. Jakarta: EGC;2009.h.1014.

9. Hartati MG. Pengaruh nefroprotektor jus paprika merah (Capsicum annuum var. gossum) terhadap kerusakan histologis sel ginjal mencit yang diinduksi parasetamol. Surakarta: Skripsi FK Universitas Sebelas Maret; 2012.

10. Damjanov I. Histopatologi: Buku teks dan atlas berwarna. Jakarta: Widya Medika;1998.h.268.

11. Ardhini R. Pengaruh pemberian ekstrak meniran (Phyllanthus sp.) terhadap gambaran mikroskopik ginjal tikus wistar yang diinduksi karbon tetraklorida. Semarang: Skripsi FK Universitas Diponegoro; 2006:16 hlm.

12. ECO-USA, 2006. Carbon tetrachlorida. http://www.eco-usa.netAoxics/ccl4.sthtml. Diakses pada tanggal 14 Maret 2016.

13. Haki M, Mukti N, Handry R, Kesit JW. Studi histologis ginjal mencit pada pemberian ekstrak daun talok (Muntingia calabura L.) dengan induksi karbon tetraklorida. Surakarta: Skripsi FK Universitas Sebelas Maret; 2009.

14. Kuntorini EM, Astuti MD, Nugroho LH. Struktur anatomi dan aktivitas antioksidan 
bulbus bawang dayak (Eluetherine americana Merr.) dari daerah Kalimantan Selatan. Berkala Penelitian Hayati, 2010;16:1-7.

15. Assiam N, Setyawati I, Sudirga SK. Pengaruh dosis dan lama perlakuan ekstrak daun kaliandra merah (Calliandra calothyrsus Meissn.) terhadap struktur histologi ginjal mencit. Jurnal Simbiosis II, 2014;(2): 236-46.

16. Hendra P, Krisnadi G, Perwita NLPD, Kumalasari I, Quraisyin YA. Efek hepatoprotektif dan nefroprotektif biji alpukat pada tikus terinduksi karbon tetraklorida. Traditional Medicine Journal, 2014;19(3):133-7.

17. Panjaitan RGP, Handharyani E, Chairul, Masriani, Zakiah Z, Manalu W. Pengaruh pemberian karbon tetraklorida terhadap fungsi hati dan ginjal tikus. Makara Kesehatan, 2007;11(1):11-6

18. Cahyaningsih RA, Azizahwati, Kusmana D. Efek nefroprotektif infus daun sukun (Artocarpus altilis (Park.) Fsb.) pada tikus jantan yang diinduksi karbon tetraklorida. Majalah Ilmu Kefarmasian, 2011;8(2):5973.

19. Meiliana N. Pengaruh pemberian ekstrak etanol umbi bawang dayak (Eleutherine palmifolia (L.) Merr.) secara oral pada mencit $\mathrm{BALB} / \mathrm{c}$ terhadap pencegahan penurunan jumlah NK sel dan CD $8^{+}$. Jurnal Biosains Pascasarjana, 2016;18(1).

20. Iskandar, FF. Pengaruh infusa bawang tiwai (Eleutherina Americana Merr) terhadap gambaran mikroskopik ginjal tikus putih jantan (Rattus Novergicus Strain Wistar) yang diinduksi uranium. Scientific Journals, 2012;8(1):54-64 